\title{
Nucleic Acid Metabolism and Depression of Hexosemonophosphate Pathway in Experimental Cardiac Hypertrophy
}

\author{
Shinsaku Matsumoto, M.D.* and Norman Krasnow, M.D.**
}

\section{SUMMARY}

The hexose monophosphate shunt activity as well as the non-oxidative pentose pathway in nucleic acids synthesis was studied in the time course of the left ventricular hypertrophy of 63 male rats weighing 200 to $600 \mathrm{Gm}$. induced by cellophane perinephritis hypertension. Another 26 rats with same range of body weight were employed as control group.

(1) Ventricular hypertrophy was estimated by the ratio of the ventricular weight to body weight, and it revealed an apparent increase of the ratio in only left ventricle ranging all body weights from 4 to 34 weeks after operation.

(2) Left heart failure was not demonstrated by determination of the water content in lungs in this series of experiment.

(3) At the early stage of the left ventricular overload, total DNA content decreased, however, during continuous overload total DNA content returned to normal, and then, at the late stage of compensated hypertrophy or of this series, this value increased over normal level. This fact suggests the possibility of cellular damage at early stage and cellular hyperplasia at late stage of ventricular overload. The incorporation ratio of $\mathrm{C}^{\mathbf{1 4}}$ glucose into DNA increased tremendously at 4 weeks after operation, which was likely an increase in degradation and synthesis of DNA. The HMP shunt activity in DNA synthesis was not detected in all course of ventricular overload.

(4) RNA content increased through all course of experiment, however, the incorporation of $\mathrm{C}^{\mathbf{1 4}}$-glucose into $\mathrm{RNA}$ increased rapidly at early stage of overload, and then returned to normal level during compensatory hypertrophy, and finally came down under normal level at late stage of compensatory hypertrophy. The HMP shunt activity in RNA synthesis was tremendously activated at carly stage of ventricular overload, but disappeared even in the compensatory hypertrophy. Therefore, the HMP shunt may be considered to play some important roles in occurrence of

From the Department of Medicine, State University of New York, Downstate Medical Center, Brooklyn, New York, U.S.A.

This work was supported by Grant U-1638, Health Research Council of the City of New York, and

Grants HE 07982 and HE 95726, U.S. Public Health Service, National Heart Institute, Bethesda, Maryland.

* Present Address: The Fourth Department of Internal Medicine, University of Tokyo, 28-6 Mejirodai-3, Bunkyo-ku, Tokyo, Japan.

** Career Scientist, Health Research Council of the City of New York (Contract I-361)

Received for publication April 21, 1972. 
cardiac hypertrophy and even cardiac failure.

\section{Additional Indexing Words:}

Nucleic acid DNA=deoxyribonucleic acid $\quad$ RNA = ribonucleic acid Hexosemonophosphate pathway Hypertrophy Hyperplasia Incorporation of radioactive carbon Cellophane perinephritis

$\mathrm{R}^{\mathrm{r}}$ ECENT studies ${ }^{41,13), 14), 17)}$ have suggested, contrary to previous work, ${ }^{1)-31}$, $5), 9\}, 101,199,201,22), 27)-29), 31$ ) that hyperplasia as well as hypertrophy plays an important role in the response of the heart to an increase in hemodynamic load. Many of these studies ${ }^{2,41,53,17,28)}$ have measured the acute or shortterm response to sudden imposition of a severe load. Some studies have utilized in vitro, or isolated heart preparations, ${ }^{23)-25)}$ and some have utilized

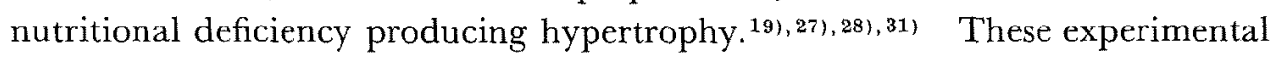
models provide useful data on the early change in response to stress, but are not necessarily closely related to the more common pathologic process of hypertrophy in human hearts which is a relatively slow change following gradual onset of hemodynamic abnormality. Also, it has not been clear whether cardiac growth induced by abnormal conditions is comparable to normal increases $n$ cardiac weight, and some authors have assumed a continuum between these 2 types of growth. ${ }^{28}$ It was our purpose to study serially the long-term response of cardiac nucleic acids to a gradually-induced hypertensive stress on the heart, and to measure incorporation rates as well as steady-state levels of deoxyribonucleic acid (DNA) and ribonucleic acid (RNA). These changes will be compared to our previous study ${ }^{16)}$ of normal cardiac growth in rats which was shown to be a continuous hyperplastic process-increase in cardiac DNA was linearly associated with increases in body weight, including the period of adult life. Continuous activity of the oxidative pathway for nucleic acid ribose synthesis was demonstrated in normal right and left ventricles of adult rats over a weight range of 150 to $600 \mathrm{Gm}$.

The results of the present study suggest that abnormally induced cardiac growth, over the range from 150 to $600 \mathrm{Gm}$. is not associated with marked increases in chromatin mass, consistent with earlier observations. It was also observed that the right ventricle participates actively in increase in cardiac RNA, but this change was not associated with increases in right ventricular to body weight ratio. In the late phase of cardiac hypertrophy, synthesis of nucleic acid pentose was dependent on non-oxidative, rather than oxidative (HMP) pathways.

\section{Materials and Methods}

One hundred male Wistar rats, weighing 200 to $600 \mathrm{Gm}$, constituted the 
experimental group, and 26 animals served as control (Group A). Data from this control group was reported in part as the control group in a previous study. ${ }^{16}$ ) The experimental animals were anesthetized with ether. The kidneys were exposed by a flank incision and wrapped with cellophane. The mortality rate was $37 \%$. The surviving 63 rats were grouped and studied in 4 periods after operation: Group B (4 weeks), 19 animals; Group C (10 to 13 weeks), 14 animals; Group D ( 17 to 19 weeks), 13 animals; and Group E (31 to 34 weeks), 17 animals. Four animals of Group A, 4 of Group B, and 1 of Group E were used for determining water content of cardiac muscle which was dried at $70^{\circ} \mathrm{C}$ for 1 week and weighed. The remaining animals of each group were divided into 2 groups, and received either glucose-1-C $\mathrm{C}^{14}$ or glucose-6- $\mathrm{C}^{14}(5 \mu \mathrm{c} / 100 \mathrm{Gm}$. of body weight, specific activity of glucose $176 \mu \mathrm{c} . / \mathrm{mM}$.) intraperitoneally 5 hours prior to sacrifice. The rats were killed by decapitation at which time blood was collected for determination of blood urea nitrogen. The heart and lungs were quickly removed and placed in ice-cold saline. The water content of lung was measured by subtracting dry weight from wet weight (dried at $70^{\circ} \mathrm{C}$ for 1 week). The heart was divided into right ventricle $(R V)$ and left ventricle (LV) including ventricular septum, weighed, and homogenized in deionized distilled water with a teflon pestlc homogenizer. Ventricular hypertrophy was indicated by an increase of ventricle/body weight ratio compared with that of the control group.

RNA and DNA were extracted by the method of Schmidt, Thanhauser and Schneider, ${ }^{30)}$ and collected as the mononucleotide in $5 \%$ perchloric acid. The concentrations of RNA and DNA were measured by the orcinol and diphenylamine method, ${ }^{30}$ respectively, and expressed per $\mathrm{Gm}$. wet weight of tissue. The radioactivity of glucose- $\mathrm{C}^{14}$ incorporated into RNA and DNA was measured with a Packard 3002 Tricarb scintillation spectrometer. The solvent system included $1 \mathrm{ml}$. of nucleic acid mononucleotide solution in 5\% perchloric acid, $8.6 \mathrm{ml}$. of absolute ethyl alcohol, and $10 \mathrm{ml}$. of toluene which contains $5 \mathrm{Gm}$. of 2,5 diphenyloxazole and $0.3 \mathrm{Gm}$. of 1,4-bis-2-(5-phenyloxazolyl)-benzene per L. of toluene.*

The activity of the hexose monophosphate shunt in nucleic acid synthesis was estimated by the difference of $\mathrm{C}^{14}$-nucleic acid from glucose-6- $\mathrm{C}^{14}$ and glucose-1-C $\mathrm{C}^{14}$. Synthesis of RNA and DNA was estimated by the incorporation of glucose-6-C $\mathrm{C}^{14}$ only.

Statistical analysis was performed by test of standard methods according to Snedecor. ${ }^{26)}$

\section{Results}

Ventricle/body weight ratios are presented in Fig. 1, as a function of body weight. Values were expressed as mean \pm standard error of the mean. The left ventricle shows higher ratios in all the operated groups than the control group (Fig. 1A). Values of the right ventricle/body weight ratio show no difference between most of the operated groups and the control group (Fig. 1B). The ratios for left ventricle were greater than control at all body weights, but were proportionately greater in the smaller animals

* Diphenyloxazole and 1,4-bis-2-(5-phenyloxazolyl)-benzene were purchased from California Corporation for Biochemical Research. 


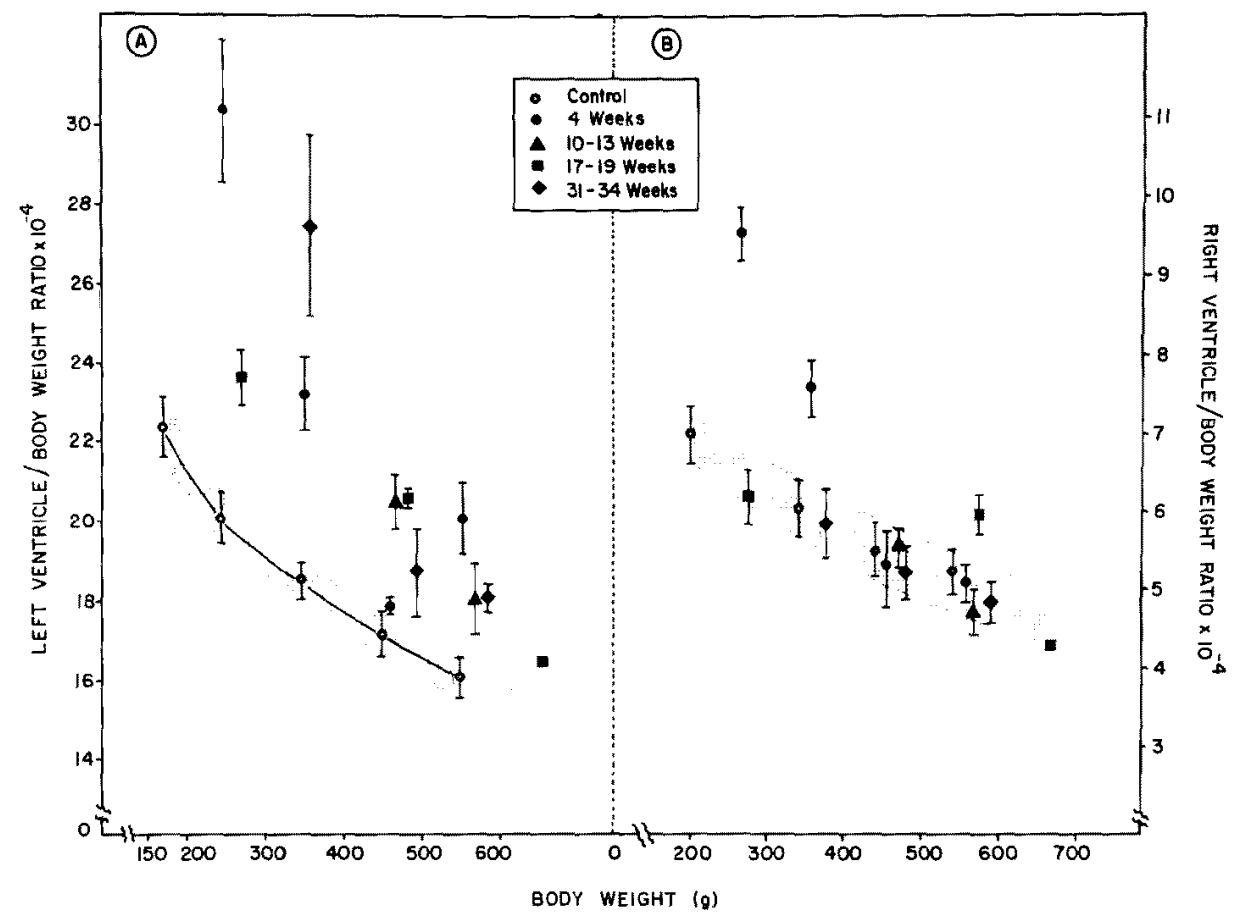

Fig. 1. Relationship between ventricular weight/body weight ratio (ordinate) and the body weight (abscissa). A: Left ventricle, B: Right ventricle. Vertical bars represent \pm standard error of the mean. Closed symbol: control; open symbols: experimental groups at specified intervals after operation.

Table I. Water Content of Cardiac Muscle and Lung, and Blood Urea Nitrogen Concentration (BUN) in the Course of Experimental Cardiac Hypertrophy

\begin{tabular}{|c|c|c|c|c|c|c|c|}
\hline \multirow{2}{*}{ Group : } & \multirow{2}{*}{\multicolumn{2}{|c|}{$\frac{\text { Normal }}{\mathrm{A}}$}} & \multicolumn{4}{|c|}{ Weeks after Operation } & \multirow{2}{*}{$\begin{array}{c}\text { Statistical } \\
\text { Significance }\end{array}$} \\
\hline & & & B : 4 & C: $10-13$ & D : $17-19$ & $\mathrm{E}: 31-34$ & \\
\hline $\begin{array}{c}\text { Water } \\
\text { content } \\
\text { of lung } \%\end{array}$ & & $\begin{array}{c}80.06 \pm \\
0.35(8)\end{array}$ & $\begin{array}{l}79.88 \pm \\
0.22(16)\end{array}$ & $\begin{array}{l}79.70 \pm \\
0.20(14)\end{array}$ & $\begin{array}{l}79.34 \pm \\
0.19(13)\end{array}$ & $\begin{array}{l}81.34 \pm \\
0.72(16)\end{array}$ & N.S. \\
\hline \multirow{2}{*}{$\begin{array}{l}\text { Water } \\
\text { content } \\
\text { of ven- } \\
\text { tricles } \\
\%\end{array}$} & $\left|\begin{array}{l}R \\
\mathrm{~V}\end{array}\right|$ & $\begin{array}{c}77.60 \pm \\
0.26(4)\end{array}$ & $\begin{array}{l}82.00 \pm \\
0.66(4)\end{array}$ & & & $80.77(1)$ & $\begin{array}{l}\mathrm{A}<\mathrm{B} \\
\mathrm{P}<.05\end{array}$ \\
\hline & $\begin{array}{l}L \\
V\end{array}$ & $\begin{array}{c}76.90 \pm \\
0.11(4)\end{array}$ & $\begin{array}{l}78.70 \pm \\
0.23(4)\end{array}$ & & & $79.92(1)$ & $A=B=E$ \\
\hline $\begin{array}{c}\text { BUN mg./ } \\
100 \mathrm{ml} \text {. } \\
\text { of serum }\end{array}$ & & $\begin{array}{l}19.2 \pm \\
1.5(8)\end{array}$ & $\begin{array}{r}26.1 \pm \\
2.5(16)\end{array}$ & $\begin{array}{r}25.8 \pm \\
2.2(13)\end{array}$ & $\frac{45.5 \pm}{3(13)}$ & $20.1 \pm$ & $\begin{array}{l}\mathrm{A}=\mathrm{B}= \\
\mathrm{C}=\mathrm{E}<\mathrm{D} \\
\mathrm{P}<.001\end{array}$ \\
\hline
\end{tabular}

Values $=$ mean \pm S.E.M

Number in parenthesis = number of animals.

N.S. = not statistically significant. 
Vol. 13
No. 4

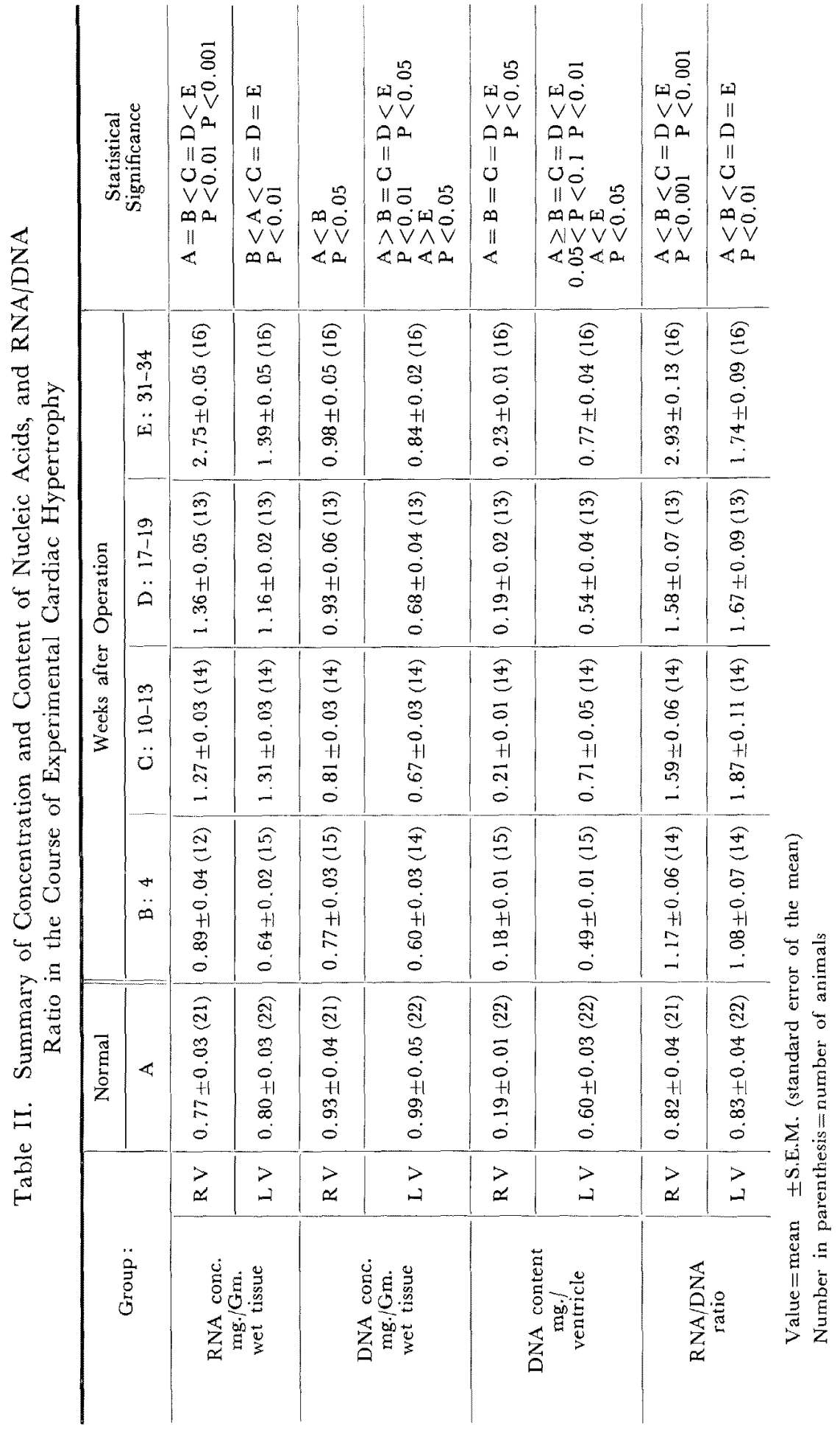


at any postoperative period.

Table I shows the water content of lungs and myocardium, and blood urea nitrogen levels (BUN) in the course of development of cardiac hypertrophy. There were no significant differences between groups in the water content of the lung. The water content was slightly increased in right ventricle only of the 4-week group $82.00 \pm 0.66 \%$, vs. $77.60 \pm 0.26 \%$ of control group $(\mathrm{p}<0.05)$. BUN concentration did not change significantly from that of control animals, except for the 17 to 19 -week group $(45 \pm 3 \mathrm{mg} . / 100 \mathrm{ml}$. vs. $19 \pm 1.5 \mathrm{mg} . / 100 \mathrm{ml} ., \mathrm{p}<0.00 \mathrm{l})$.

Nucleic acid content and concentration, and $R \mathcal{N A} / D \mathcal{N A}$ ratio (Table II and Fig. 2): Total DNA content was increased significantly only in the 31 to 34-week group, both in the LV $(0.77 \pm 0.04 \mathrm{mg}$. vs. $0.60 \pm 0.03 \mathrm{mg}$. in the control group, $\mathrm{p}<0.01)$ and the $\mathrm{RV}(0.23 \pm 0.01 \mathrm{mg}$. vs. $0.19 \pm 0.01 \mathrm{mg}$. in the control group, $\mathrm{p}<0.05)$. DNA concentration of the left ventricle decreased significantly in the early stage of left ventricular overload (4-week group), $0.60 \pm 0.03 \mathrm{mg}$. compared to the control group $0.99 \pm 0.05 \mathrm{mg}$. DNA concentration then increased somewhat in the next stages but did not regain the normal level: 10 to 13 -week group, $0.67 \pm 0.03 \mathrm{mg}$; 17 to 19 -week group, $0.68 \pm 0.04 \mathrm{mg}$; $\quad$ and 31 to 34 -week group, $0.84 \pm 0.02 \mathrm{mg}$. $(\mathrm{p}<0.01)$. DNA concentration of the right ventricles showed a similar pattern of change as in the left ventricle, with initial fall in 4 -week group $(0.77 \pm 0.03 \mathrm{mg}$., vs. $0.93 \pm$ $0.04 \mathrm{mg}$. of control, $\mathrm{p}<0.05)$, and gradual recovery to normal levels in 17 to 19 -week group $(0.93 \pm 0.06 \mathrm{mg}$.) and 31 to 34 -week group $(0.98 \pm 0.05 \mathrm{mg}$.).

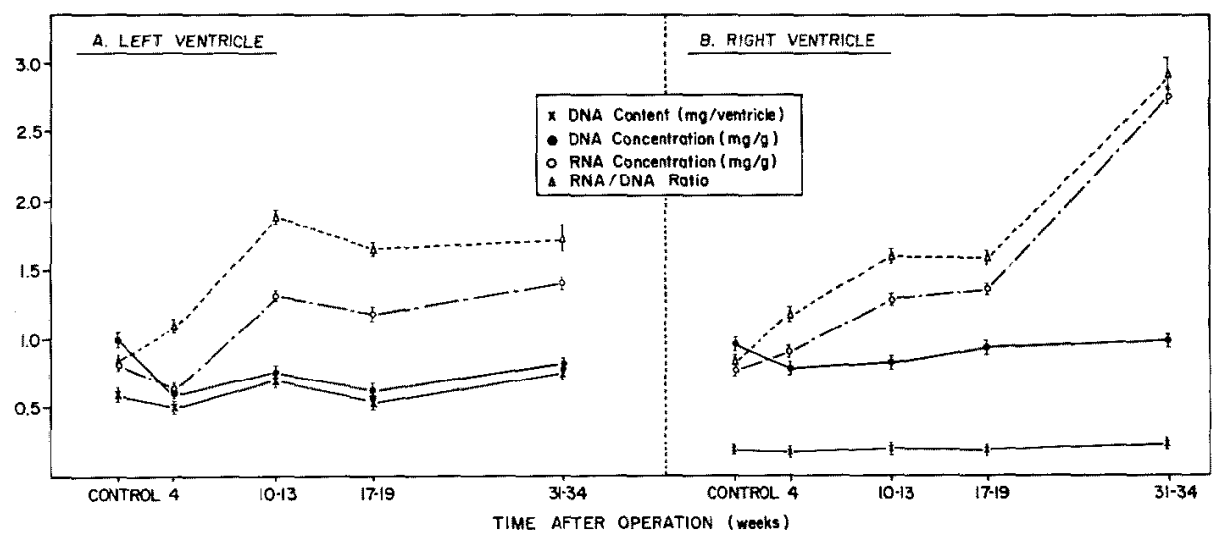

Fig. 2. The time course of change of DNA and RNA concentration (mg. $/ \mathrm{Gm}$. wet tissue), RNA/DNA ratio, and total DNA content (mg. per ventricle) during left ventricular overload. Abscissa, time after kidneywrapping operation. Ordinate: concentration of DNA ( $)$ and RNA (O), mg. $/ \mathrm{Gm}$. of wet tissue; RNA/DNA ratio $(\Delta)$; content of DNA (X), mg./ventricle. 
RNA concentration per $\mathrm{Gm}$. of wet tissue increased in both ventricles in almost all groups with hypertrophy except for an initial fall in LV of the 4-week group $(0.64 \pm 0.02 \mathrm{mg}$. vs. $0.80 \pm 0.03 \mathrm{mg}$. of control, $\mathrm{p}<0.01)$. The degree of maximum increase in RNA concentration above control was greater in right ventricle $(350 \%)$ than left ventricle $(170 \%)$.

The RNA/DNA ratio of operated groups was persistently higher in the operated groups in both right and left ventricles than control $(\mathrm{p}<0.001)$. The time course of change in RNA/DNA ratio paralleled the change in RNA concentration.

Incorporation of $\mathrm{C}^{14}$-glucose into nucleic acids: Table IIIA and Fig. 3 show the time course of incorporation of $\mathrm{C}^{14}$-glucose in RNA of cardiac muscle. There was an increase in incorporation of G-6-C ${ }^{14}$ per $\mathrm{Gm}$. tissue in both right and left ventricles, beginning at 4 weeks and extending through the 10 to 13 week period. RNA content was rising during this period however (Fig. 2 ), so specific activity increased only in LV, and only in the 4-week group. Incorporation of G-1-G14 per Gm. tissue also increased in both $L V$ and $\mathrm{RV}$,

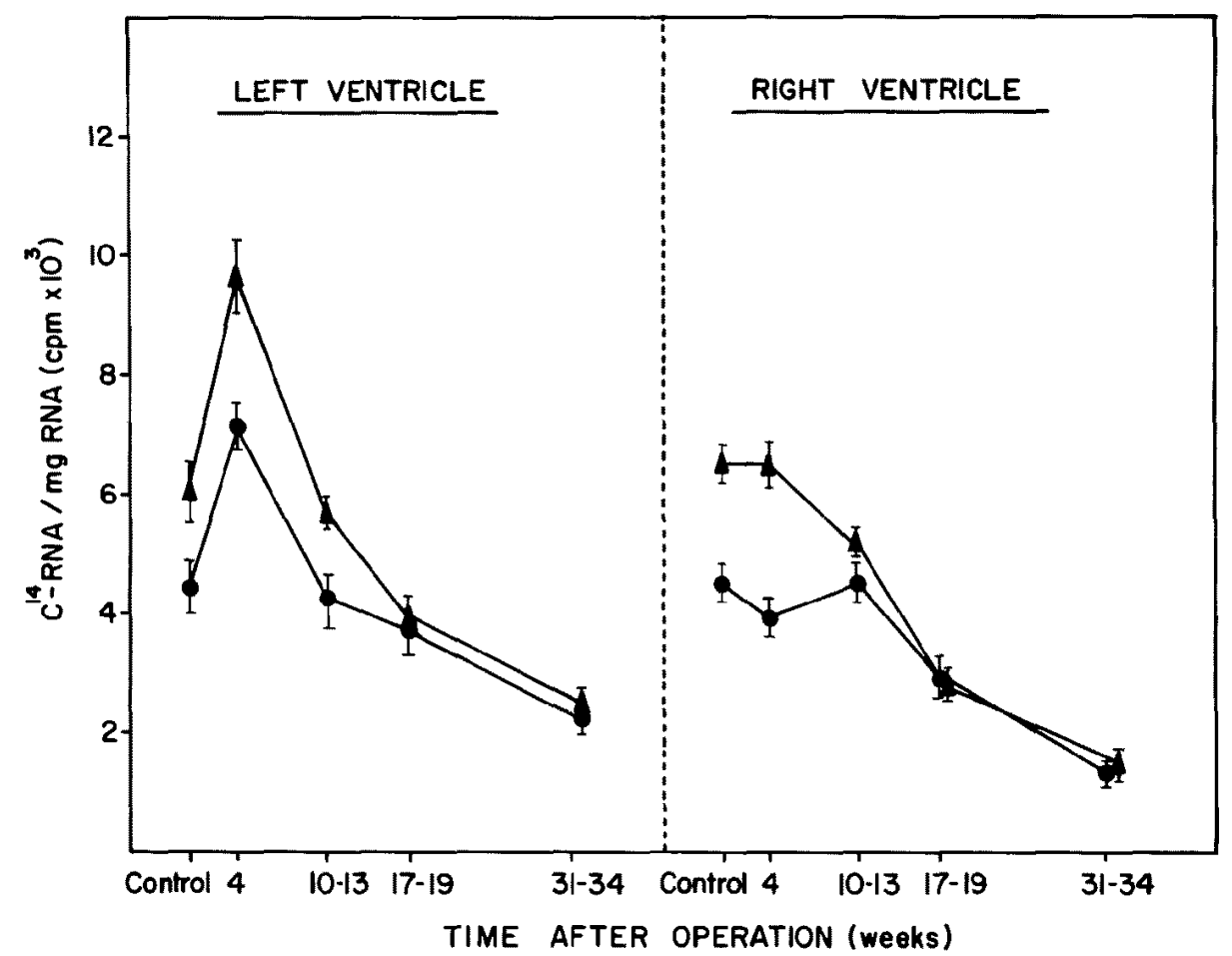

Fig. 3. The time course of incorporation of glucose-C ${ }^{14}$ in to RNA per mg. RNA during development of cardiac hypertrophy. Abscissa: time after operation. Ordinate, counts per min. of $\mathrm{C}^{14}$-RNA/per mg. RNA.

$1-\mathrm{C}^{14}, \mathbf{A}=\mathrm{G}-6-\mathrm{C}^{\mathbf{1 4}}$. Vertical bars represent \pm standard error of the mean. 


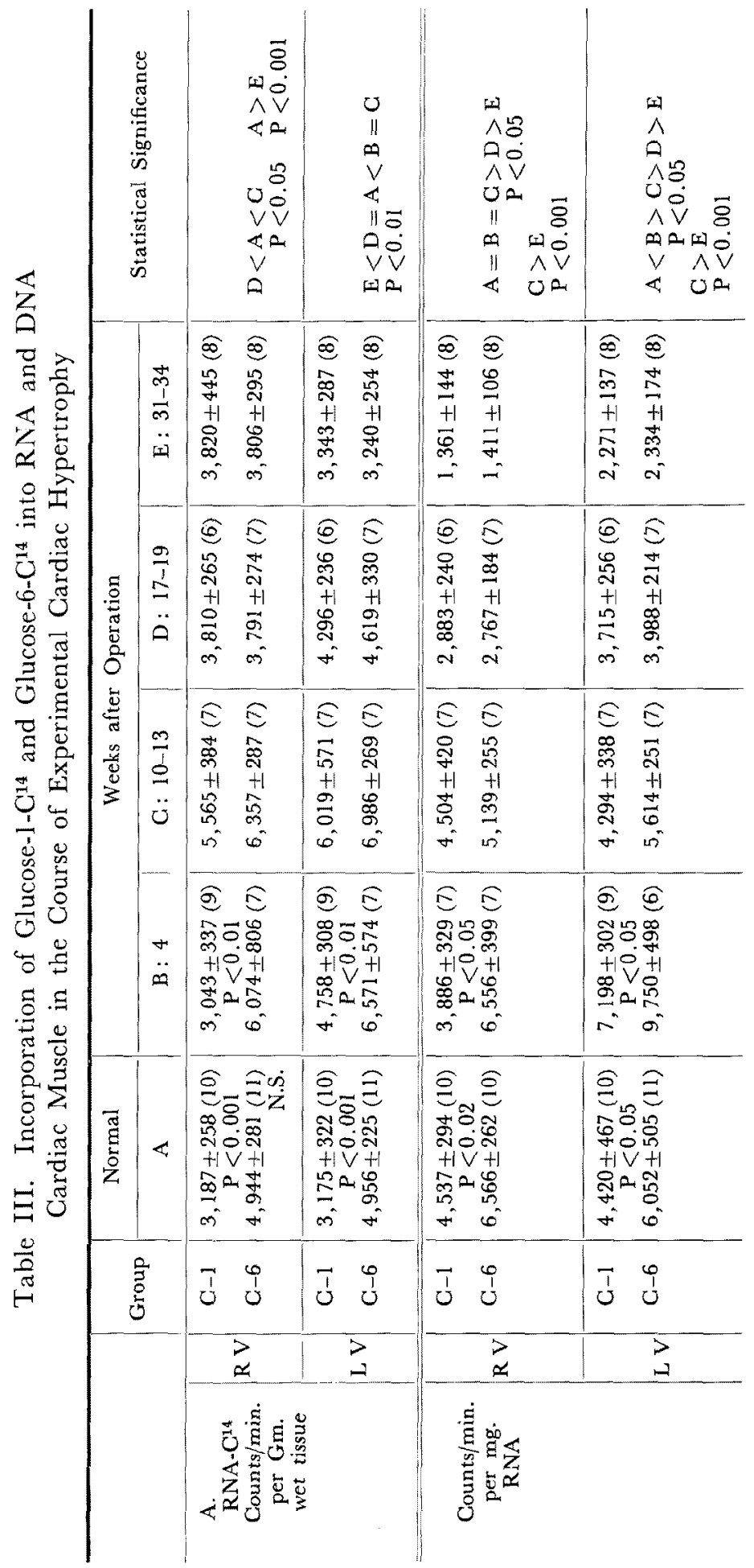


Vol. 13

EXPERIMENTAL GARIAC HYPERTROPHY

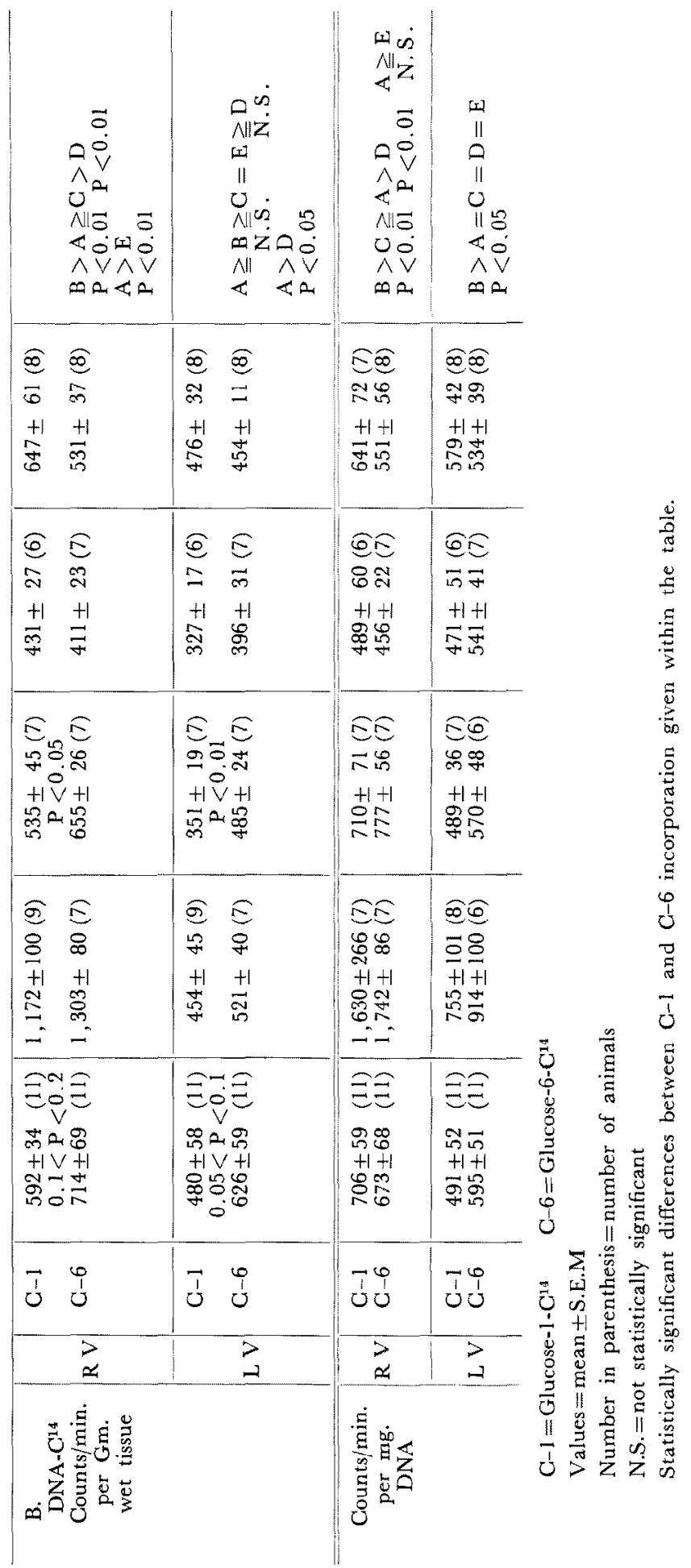


reaching a peak somewhat later than $\mathrm{G}-6-\mathrm{C}^{\mathbf{1 4}}$ (Table IIIA). As with G-6-C ${ }^{14}$, specific activity of the G-1-C ${ }^{14}$ labelled RNA showed increases only in LV in the 4-week group.

Incorporation of G-6-C $\mathrm{C}^{14}$ into RNA of left and right ventricle, calculated per Gm. of wet tissue and per $\mathrm{mg}$. of RNA, was significantly greater than that of $\mathrm{G}-1-\mathrm{C}^{14}$ in the control group. The difference between incorporation of G-6-C $\mathrm{C}^{14}$ and G-1-C $\mathrm{C}^{14}$ increased further in the 4-week group, but then declined, no difference being observed in later groups. The incorporation of G-1-C ${ }^{14}$ into RNA of $\mathrm{LV}$ and RV also increased, but somewhat more slowly than G-6-C ${ }^{14}$, and reached a peak at 10 to 13 weeks after operation (Fig. 3B).

Table IIIB and Fig. 4 show the time course of incorporation of $\mathrm{C}^{14}$ glucose into DNA of cardiac muscle. There was an increase in incorporation

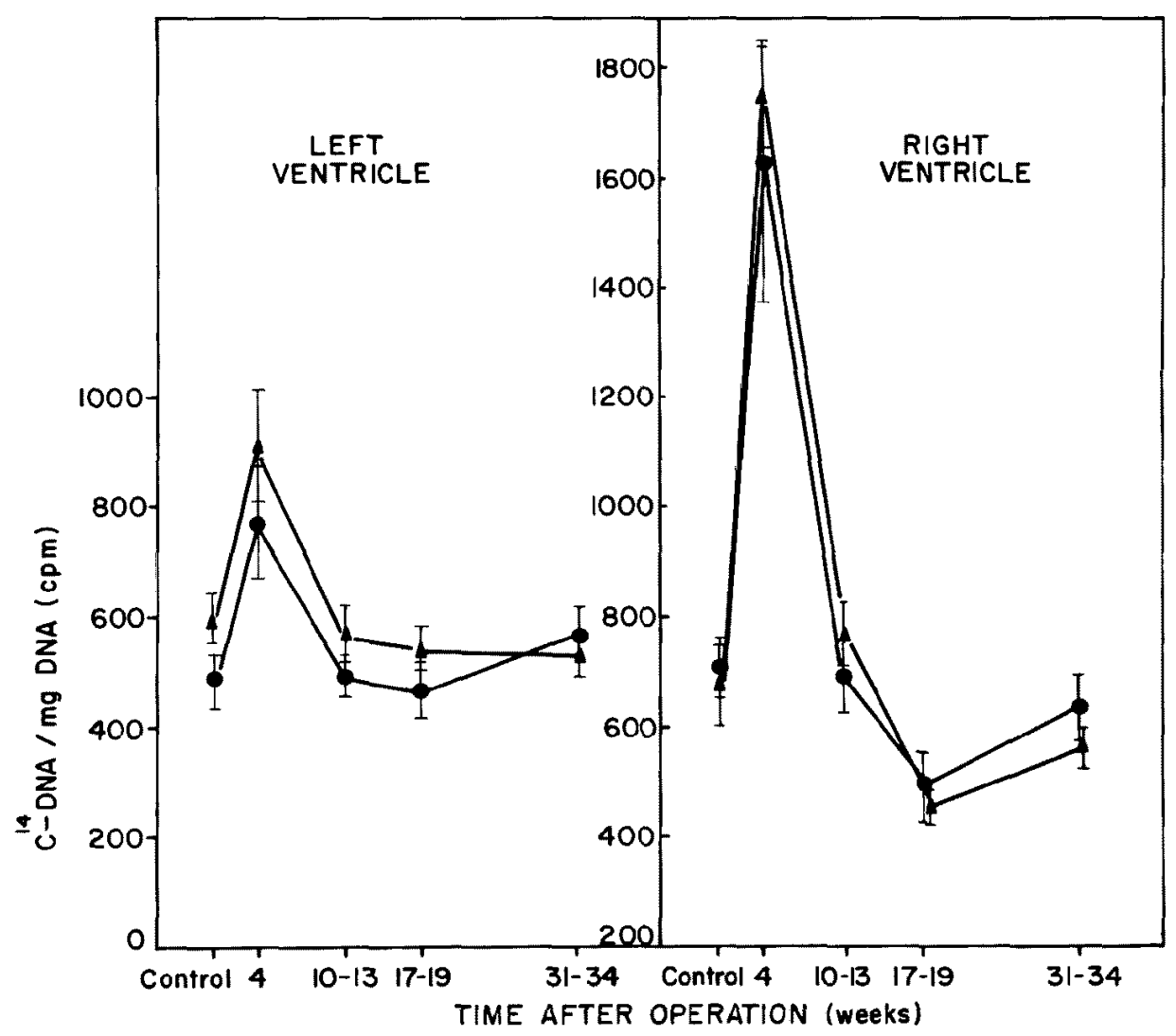

Fig. 4. The time course incorporation of glucose-C ${ }^{\mathbf{1 4}}$ into DNA per mg. of DNA during development of cardiac hypertrophy. Abscissa: time after operation. Ordinate: counts per min. of $\mathrm{C}^{14}-\mathrm{DNA}$, per mg. DNA. $=\mathrm{G}$ $1-\mathrm{C}^{14}$, and $\mathbf{A}=\mathrm{G}-6-\mathrm{C}^{14}$. 
rate of G-6-G $\mathrm{C}^{14}$ per mg. DNA in both left and right ventricles, reaching a peak at 4 weeks and declining to control levels or below thereafter. Increased incorporation per Gm. tissue was seen only in RV in the 4-week group (Table IIIB). The increased incorporation of $\mathrm{G}-6-\mathrm{C}^{14}$ per mg. DNA was greater in $\mathrm{RV}$ than $\mathrm{LV}$, whether measured as specific activity or absolute increase in counts per $\mathrm{Gm}$. tissue.

Incorporation of G-6-C $\mathrm{C}^{14}$ into DNA of left and right ventricles was equal in the control group and continued to be closely parallel in the hypertrophied groups. Incorporation was increased in both ventricles only in the 4-week group. This was the period when DNA content in LV declined significantly (RV: $\mathrm{p}<0.01 ; \mathrm{LV}: \mathrm{p}<0.05 ;$ Table II). Thereafter, incorporation in later groups was similar to that in the control group. There were then no significant differences between incorporation of G-1-C $\mathrm{C}^{14}$ and $\mathrm{G}-6-\mathrm{C}^{14}$ into DNA at any stage of cardiac hypertrophy.

\section{Discussion}

The response of the mammalian heart to a chronic disease or increase in work load has generally been thought to consist in a hypertrophic process, with increase in tissue RNA content, no change in DNA content, and a consequent rise in RNA/DNA ratio. Recent studies have demonstrated early stimulation of microsomal amino-acid incorporation by acute overload in isolated hearts ${ }^{20), 24}$ or in cell-free extracts of skeletal muscle. ${ }^{8}$ ) Increased numbers of microsomes have been reported $^{8)}$ as well as increased activity of pre-existing microsomes. ${ }^{24}$ However, the constancy of DNA content has been questioned, and increases in $\operatorname{cardiac}^{(6), 13), 18)}$ or skeletal ${ }^{8)}$ muscle DNA content have been observed.

In a previous study on normal rats, ${ }^{16)}$ it was found that DNA content as well as RNA concentration of rat hearts increased linearly with ventricular and body weight in the normal process of growth, cven into adult life. This increase in DNA content indicated that normal growth in the rat is a continuous hyperplastic process. Peterson and Baserga, ${ }^{22}$ ) on the other hand, observed a levelling-off of DNA content after mice reached 4 months of age, but cardiac and body weight increased relatively little in these animals after this time. Our present data, however, show little or no change in DNA content, similar to results of Tomita ${ }^{29 !}$ suggesting that the cardiac hypertrophy developing in the course of hypertension secondary to cellophane perinephritis is not similar to the cardiac enlargement associated with normal growth. This is consistent with earlier interpretations, namely that hypertrophy alone is the primary response to stress with increases in cell mass but without in- 
crease in number of cells or mass of chromatin material. The small increase in DNA content in the 31 to 34 -week group is significantly greater than control DNA values, but the DNA levels in the left ventricle fluctuated somewhat, and the significance of this value is not certain.

The sharp transient increase in DNA incorporation into $L V$ and $R V$ at 4 weeks were not followed shortly thereafter by measurable changes in DNA content in $R V$, and were associated with declines in DNA content in LV. These data suggest an early period of cellular damage or increased catabolism, with increased synthesis of DNA partially maintaining a steadystate level of DNA content. The increases in DNA content observed by others $^{6), 18)}$ may relate in part to the more severe, acute hypertensive strain produced. Polyploidy played a role in this DNA increase ${ }^{6)}$ but not to the extent found by Kompmann, Paddago, and Sandritter. ${ }^{13)}$ In any event the increased DNA noted by these observers has been localized by them histologically and autoradiographically to connective tissue and vascular cell, not muscle cell.

The response of the right ventricle to the perinephritis is unexpected and unusual. In the left ventricle there was an early increase in incorporation rate of glucose- $\mathrm{C}^{14}$ into $\mathrm{RNA}$ with subsequent rise in RNA concentration and in $\mathrm{LV} /$ body weight ratio, as expected, which was thereafter maintained. On the other hand, there was no RV hypertrophy in the majority of the operated rats, as shown by the normal $\mathrm{RV} /$ body weight ratio (Fig. 1). The 4-week group alone shows some increase in $\mathrm{RV} /$ body wcight ratio, which may in part be attributed to the significant increase in water content of the ventricles during this phase (Table I). However, while DNA content remained constant, RNA incorporation per Gm. tissue was increased and RNA concentration increased markedly and progressively. Indeed the 31 to 34-week group had greater increases in RNA than the left ventricle. The RNA/DNA ratio was significantly increased, although ventricular weight was unchanged from control (Fig. 1B). Gluck et al.4) also noted a rise in RNA content and in RNA/DNA ratio and Morkin ${ }^{18)}$ found increases in RNA concentration in the right ventricles of rats soon after acute aortic constriction. No data are given for right ventricular weight in either study. The RNA/DNA ratio is therefore not, per se, a reliable index of hypertrophy, as previously suggested. The explanation for the observed dissociation between increase in RNA without subsequent increase in tissue mass is not clear. If the increase in right ventricular RNA is explained simply by an increase in hemodynamic load, i.e. secondary to increased left ventricular preload or afterload, one would expect an increase in RV weight as well. It is possible that the stimulus to hypertrophy when a ventricle is overloaded leads to a generalized increase in 
RNA in the entire heart, but the translation into increased protein synthesis could require additional factors present specifically in the overloaded ventricle alone. It is not known whether the increases in RNA observed include both messenger RNA and ribosomal RNA. Schreiber et al. ${ }^{24)}$ found increased protein synthesis in RV (unloaded) of isolated heart preparations. He suggested increase in protein degradation rate to account for decreased protein level. Gudbjarnason, Telerman, and Bing ${ }^{71}$ did not find any change in protein catabolism in more chronic studies. In acutely hypertrophied skeletal (soleus) muscle, however, Hamosh et al. ${ }^{8)}$ reported that increase in incorporation of labelled leucine was a function of increased ribosomal RNA, regardless of the origin of their $\mathrm{pH}-5$ enzyme in the assay system. It is also possible that the dependency of left ventricular weight on age and body-weight may apply as well to the right ventricle. In this group of animals, which were not restricted to a single age and body-weight range, small changes in RV weight may thus have been obscured. However, the major magnitude of increase in RNA incorporation and RNA content would suggest that weight changes were not obscured by these considerations. Also, we found previously that DNA concentration was inversely related to body weight in left ventricle but not right ventricle. Finally, increased coronary blood flow secondary to aortic hypertension could play a role in stimulating RNA and protein synthesis ${ }^{21}$ in the normally loaded RV.

Hexose monophosphate shunt:

During the early phase of increased nucleic acid synthesis, presumably a period of uncompensated hemodynamic load induced by the cellophane perinephritis, the activity of the HMP shunt in RNA pentose synthesis was significantly increased in left ventricle, and to a lesser extent in right ventricle. This was reflected qualitatively by the increase in $\mathrm{C6} / \mathrm{C} 1$ ratio of glucose$\mathrm{C}^{14}$ incorporation (Fig. 3). ${ }^{11}$ Recycling of intermediate products between the oxidative and non-oxidative pathways for ribose synthesis prevents the $\mathrm{C} 6 / \mathrm{Cl}$ ratio from assuming more quantitative importance. No change in $\mathrm{C} 6 / \mathrm{Cl}$ ratio was observed in DNA incorporation of glucose- $\mathrm{C}^{14}$, despite the increased activity demonstrated. In the later stages of ventricular overload, the incorporation rate of glucose- $\mathrm{C}^{14}$ into $\mathrm{RNA}$, expressed as specific activity of glucose- $\mathrm{C}^{14}$ was depressed. This probably represents a phase of compensatory hypertrophy, at least in left ventricle, with diminished percentage turnover of nucleic acid, although total incorporation per $\mathrm{Gm}$. of tissue was normal. The activity of the HMP shunt also disappeared, the $\mathrm{C6} / \mathrm{C} 1$ ratio approaching unity. In normal rats, conversely, ${ }^{16)}$ progressive increase in heart weight was not associated with depression of HMP shunt activity and may actually have a somewhat increased activity. Thus the preferential synthetic pathways in RNA me- 
tabolism, as well as the overall change in DNA content, are significantly different during chronic cardiac hypertrophy secondary to an exogenous hemodynamic load, compared with the increase in heart weight secondary to normal growth. This depression of the HMP shunt is probably not related to general depression of nucleic acid metabolism, since incorporation of glucose- $\mathrm{C}^{14}$ in the 10 to 13-week group was similar in degree to control (Fig. 3), but the C6/C1 difference was abolished. Conversely, increased glucose incorporation into DNA was not necessarily associated with increased activity of the shunt pathway. Since only one group of animals manifested elevated blood urea nitrogen levels, it is unlikely that depression of HMP activity in the other groups was related to uremia. Finally, the depression of HMP shunt activity has been observed in similar experiments in vitro. ${ }^{12), 15)}$ Abolition of the C6/C1 ratio could represent therefore a subtle manifestation of tissue (cardiac) hypoxia, not otherwise demonstrable, with preferential utilization of oxidative metabolism to meet the increased work load.

\section{REFERENCES}

1. Black-Schaffer, B. and Turner, M. E.: Am. J. Pathol. 34: 745, 1958.

2. Capers, T. H.: Am. Heart J. 68: 102, 1964.

3. Dammin, G. J. and Moore, R. A.: Arch. Pathol. 27: 122, 1939.

4. Gluck, L., Talner, N.S., Stern, H., Gardner, T. H., and Kulovich, M. V.: Science 44; 1244, 1964.

5. Grimm, A. F., Kubota, R., and Whitehorn, W. V.: Circulat. Res. 19: 552, 1966.

6. Grove, D., Zak, R., and Nair, K. G.: Clin. Res. 16: 231, 1968.

7. Gudbjarnason, S., Telerman, M., and Bing, R. J.: Am. J. Physiol. 206 : 294, 1964.

8. Hamosh, M., Lesch, M., Baron, J., and Kaufman, S.: Science 157: 935, 1967.

9. Hoyle, T. G., III, Sumner, R. G., and McIntosh, H.: J. Lab. Clin. Med. 62: 632, 1963.

10. Karsner, N. T., Saphir, O., and Todd, T. W.: Am. J. Pathol. 1: 351, 1925.

11. Katz, J., and Wood, H. G.: J. Biol. Chem. 235: 2165, 1960.

12. Kobayashi, T., Ito, Y., Kishiii, T., Matsumoto, S., and Kaku, I.: Shinryo 19: 741, 1966 (in Japanese).

13. Kompmann, M., Paddago, I., and Sandritter, W.: Arch. Pathol. 82: 303, 1966.

14. Linzbach, A. J.: Am. J. Cardiol. 5: 370, 1960.

15. Matsumoto, S., Kishii, T., Ito, Y., and Kobayashi, T.: Jap. Heart J. 6: 443, 1965.

16. Matsumoto, S. and Krasnow, N.: Am. J. Physiol. 214: 620, 1968.

17. Meerson, F. Z., Beloshapkina, T. D., Lushnikov, E. F., Leikina, E. M., Markovskaya, G. N., and Chernyshova, G. V.: Fed. Proc. 23: T667, 1964.

18. Morkin, E.: Clin. Res. 16:241, 1968.

19. Norman, T. D. and Carter, W. J.: Fed. Proc. 20: 128, 1961.

20. Nowy, H., Frings, H. D., and Rey, K.: Experientia 15: 70, 1959.

21. Opie, L. H.: J. Physiol. 180:529, 1965.

22. Petersen, R. O. and Baserga, R.: Exptl. Cell Res. 40: 340, 1965.

23. Schreiber, S. S., Evans, C., Oratz, M., and Rothschild, M. A.: Am. J. Physiol. 212: 35, 1967.

24. Schreiber, S. S., Oratz, M., and Rothschild, M. A.: Am. J. Physiol. $213: 1552,1967$.

25. Schreiber, S. S., Oratz, M., and Rothschild, M. A.: Am. J. Physiol. 211 : 314, 1966.

26. Snedecor, G. W.: Statistical Methods, Ames, Iowa, Iowa State University Press, 1956. 
27. Sumner, R. G., Hoyle, T. G., III, McIntosh, H. D., and Whalen, R. E.: Am. J. Physiol. 207: $1102,1964$.

28. Sumner, R. G. and McIntosh, H. D.: Circulat. Res. 12: 170, 1963.

29. Tomita, K.: Jap. Heart J. 7: 566, 1966.

30. Volkin, E. and Gohn, W. E.: Methods Biochem. Anal. 1: 287, 1954.

31. Widdowson, E. M. and McGance, R. A.: Brit. J. Exptl. Pathol. 36: 175, 1955. 